\title{
Service Quality and Reputation Toward Customer Trust in Life Insurance Corporation
}

\author{
L. Lisnawati, Girang Razati, Henny Mulyani \\ Faculty of Economic and Business Education \\ Universitas Pendidikan Indonesia \\ lisnawati@upi.edu
}

\begin{abstract}
The low of customer trust is discussed on insurance sector. Companies should pay attention to this aspect because trust plays an important role in the engagement of longterm relationship between company and consumers in insurance services. Zurich Gold Lion is one of the insurance company which has a problem with customer trust. This study aims to identify and measure the impact of service quality and reputation on customer trust. This research applies descriptive verification method and research data is collected from 150 respondents of Zurich Gold Lion customer by multiple regression analysis techniques. It is discovered that service quality and reputation positively affected customer trust, service quality positively affected $35,8 \%$ customer trust while reputation affected $7 \%$ on customer trust. In addition, a factor in building a good service quality is the quality of interaction between service provider and customer, while the workplace environment is a factor in creating perceptions of the customer to the company's reputation.
\end{abstract}

Keyword--- Service Quality, Corporate Reputation, Customer Trust Article Type---Research paper

\section{INTRODUCTION}

Trust has become a great issue of discussion in business, academics and the media. The discussion found that lack of customer trust happened in many industries [1]. High level of trust in agreement is very needed because it will be done for a long period of time. Creating a good relationship with customers and increasing the trust is the key to influence customers' perception toward company [2].

Research conducted on the insurance sector in Ethiopia faced the same problems as well, it is the low of trust that showed from a decrease in the number of customers that affect the company's premium [3]. This condition forced the company to increase customer loyalty by improving customer trust. Improving trust is a strategy to create long-term relationships. In developing management of relationship between consumers and companies, it is very important for a business to pay attention to the detail level of consumer trust and commitment to the company [4].

According to Asosiasi Asuransi Jiwa Indonesia (AAJI) the insurance penetration in Indonesia is still below 3\%, this condition describe that the growth of insurance business is not significant until 2015. Data from the OJK (Otoritas Jasa Keuangan) showed that conventional for life insurance industry become the sector with the lowest growth assets throughout 2015. After declining $0,3 \%$ in 2014 , life insurance industry premium income decreased to $9,3 \%$ in 2015 . These conditions illustrate that there are still many people who do not have a trust to use a service insurance.

Empirical data and previous studies showed that the level of trust toward company is still low. If it is not directly handled, it can be affected to the different issues. There is the need to solve this problem in the exact time in order to keep and develop the customer trust toward company.

Zurich Gold lion is one of the insurance corporations in Indonesia. This company also faces the same issue as well it is the lack of customer trust, and it is indicated from increasing number of complain, customer loss, and under standard corporate persistence. The complains contain of agent explanation that didn't relevant to reality and the unclear information, time period of disbursement customer claims are slow, and agent's explanations are not detail. The proper solution for the company is to improve service quality and reputation so that customer trust is back.

The solution aims to improve the perception of customer trust, so that customers will keep investing to the company. To prove the effect of service quality and reputation toward customer trust is still needed to be investigated by conducting a survey to customers.

\section{LITERATURE}

Marketing is the activity, set of institutions, and processes for creating, communicating, delivering, and exchanging offerings that have value for customers, clients, partners, and society at large [5].

Marketing is not only about goods but also service. Services are a form of product that consists of activities, benefits, or satisfactions offered for sale that is essentially intangible and do not result in the ownership of anything [6]. Service that is delivered must have a good quality, service quality is general assessment of a person to the excellence services provided by comparing expectations and reality [7-9]. The dimension used to measure service quality are interaction quality, physical environment quality, and outcome quality [10].

Providing services will create a personal relationship, if it is given greatly, then the relationship will improve consumer trust, and vice versa. Several studies reveal that service quality influences customer trust [11-13]. The higher level of service quality provided, the higher level of trust accepted by company. The successful and sustainable of company in competitive environment depends on the company's ability to produce services according to customer needs [14], then the 
quality of service is a very influential component in enterprise competition [15].

Besides service quality, increasing reputation may affect trust, reputation can be defined how an entity (private or public) perceived by each stakeholder group, and reputational risk as the risk that an event will affect stakeholders' perceptions negatively [16]. Reputation is accumulation assessment of individual or group against the company or organization to give satisfaction created from time[17-20]. Reputation measurement can be performed using the dimensions of Fombrun [21] consisted of product and service, vision and leadership, workplace environment, financial performances, social responsibility, and emotional appeal.

Reputation can help a company to achieve competitive advantage, improve market performance, and customer value that will ultimately increase the confidence in the company [17]. An identity and reputation of the company are able to create and boost consumer confidence, supported by the best service to consumers who will ultimately affect consumer loyalty in the long term [2]. Company with a good reputation is very useful in building consumer trust, the trust will affect the consumer's commitment to the company [22]. Reputation has a positive and significant impact on consumer trust, the excellent reputation of the company is an invisible asset for the sustainability of the company, beside the reputation of the company can maintain in facing the crisis [23]. An individual who believes a company's reputation will cause consumer trust [24].

Trust is the willingness of a party to be vulnerable to the actions of others, and others believe that companies are competent, open, caring, honest, and reliable [25-27]. It is believed that a service provider can establish long-term relationships with consumers [28]. Dimensions in measuring the trust consisted of ability, benevolence and integrity [25]. According to the explanation above, here is the research paradigm:

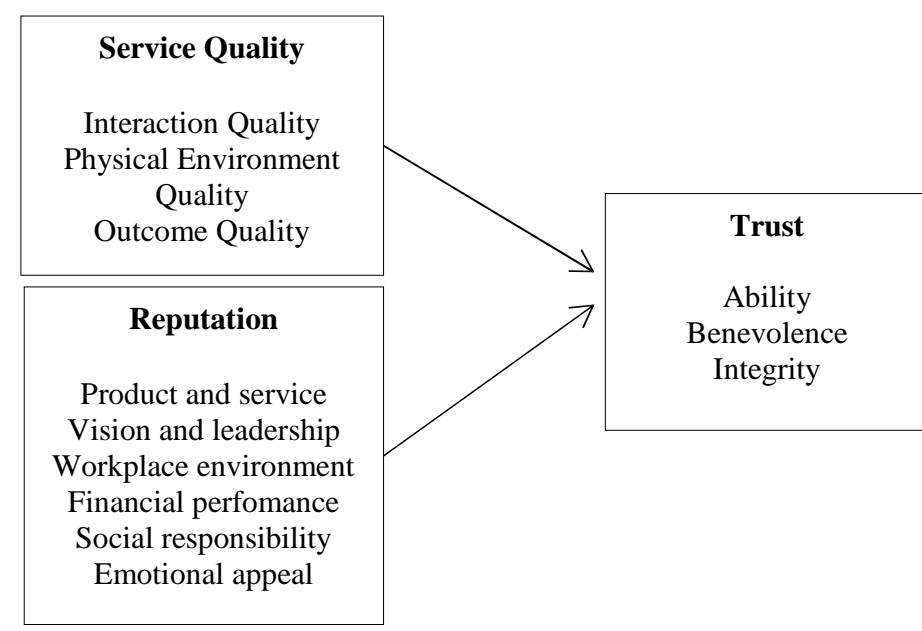

Fig. 1 Research paradigm

\section{RESEARCH METHODELOGY}

This study investigates service quality and reputation and its influence on consumer trust through marketing management approach. The independent variable of this research is service quality and reputation while dependent variable is customer trust.

Based on the aim and the variables stated above, this research is categorized as a descriptive and verification research. This research tests the hypothesis of the influence of service quality and reputation on customer trust in life insurance corporation. This research was done in less than one year using cross sectional method. The technique used is survey research and analysis unit is Zurich Gold Lion customer. This study examined 150 respondents using simple random sampling. Data collection techniques used were interviews, questionnaires, and literature study. Meanwhile, verification of data analysis techniques using multiple linier regression using SPSS 21.0 for Windows.

\section{FINDINGS AND DISCUSSIONS}

Companies that are able to provide the best service will create commitment and trust in the company to continue using the service. Supported by the good reputation that will make customers become increasingly trust to the company. The reputation able to have a positive impact, increasing customer trust, profits are up, and be able to retain customers despite the financial crisis.

The analysis test used multiple linier regression analysis in order to measure the impact of service quality and reputation on customer trust. This is the following result:

$$
\mathrm{Y}=6,568+0.305 \mathrm{X} 1+0.166 \mathrm{X} 2
$$

Based on the multiple linear regression equations above, the constant of 6.568 , stating that if there is no service quality and reputation then the value of customer trust is 6.568 The regression coefficient variable quality of service of the unit value of 0.305 means that any increase in the service quality will increase customer trust by 0,305 of the unit value and vice versa if a decline in service quality, customer trust will decrease by 0,305 of the unit value. While the regression coefficient of variable reputation of the unit value of 0.166 means that whenever there is an increase reputation will increase customer confidence by 0.166 of the unit value and vice versa if the decline in reputation, it will lower customer confidence in the unit value of 0.166 .

After that, this research was studied by significance test (Ftest) with standard of significance is $5 \%$. The result shows that Fcount is 160,358 and Ftable is 3,06 (Fcount $>$ Ftable) so we can see that Ho is declined, and $\mathrm{H} 1$ is accepted and the conclusion is that regression is signified.

Aside from Ftest, the research was studied with regression of a coefficient significance test ( t-test), with one side test of ttabel and 0,05 or $5 \%$ standard of significance. Then it is known that df150-3=148 (n-k) and can be known through the t-test of 7,643>1,976 for the service quality and for the reputation of $3.376>1,975$, It means service quality and reputation has positif impact on customer trust.

The success and survival of the company in a competitive environment depends on the company's ability to produce services base on the customer needs [14], the quality of service is a very influential component of competitive companies [15]. If the company can provide good quality and satisfying service, 
then it can establish a corporate image and build trust and a sense of comfort for the customers [13].

Interaction quality consists of insurance knowledge, attitudes and behavior have become important factors in providing services because it will build customer quality perceptions. The quality of the interaction that occurs between the customer's experience with the service providers. In fact, it has become a vital factor that will make the customer feel satisfied [29]. Knowledge, attitudes, and behavior of service providers in the interaction became very important [30], therefore the interaction is at the heart of a customer's experience.

Reputation also plays an influential role in a business, the company has a good reputation has several advantages such as creating barriers to entry other markets, maintaining the memory of customers, and strengthen a competitive advantage [31]. Workplace environment dimensional becomes an important factor in building customer perception of the company's reputation, which is obtained from the customer's view of Zurich impressed either party in the eyes of the customer. If the condition mantained and enhanced perfectly, to company reputation will be improved. A fundamental thing to company reputation lies on the quality the staff of the organization, how their motivation and ability. How employees are treated will affect the reputation of a company associated [17].

\section{CONCLUSION AND RECOMMENDATION}

Based on the result of the descriptive and verificative analysis by employing multiple linear regressions between service quality and reputation toward customer trust, service quality and reputation have a positive influence on trust. On service quality, quality of interaction has the highest score for service quality, then it is should be improved and maintained by improving knowledge, attitudes, and behavior of the company, with a good process, the customer will be satisfied and had an excellent perception toward company.

Workplace environment is an important factor in building a reputation, it is shown from this research that it has the highest score at reputation variable. Good perception of company and all the elements inside has contributed for reputation perception. Employee's competency will satisfy customers and created a confidence that the insurance company is the right place to invest and establish long-term relationships in financial aspect.

The ability of company has a high contribution in creating customer trust. This study showed that Zurich is considered to have qualified in delivering service or having a good ability to carry out the roles and obligations to the customers. Zurich must improve ability of employees, agents, and all parties that are responsible for providing services to the customers so that the company will have a positive value in the future.

\section{REFERENCES}

[1] Halliburton C, Poenaru A. The Role of Trust in Consumer Relationships. ECSP Eur. 2011;0-16.

[2] Nguyen N, Leclerc A, Leblanch G. The Mediating Role of Customer Trust on Customer Loyalty. J Serv
Sci Manag [Internet]. 2013;06(6):96-109. Available from:

http://www.scirp.org/journal/PaperDownload.aspx?D $\mathrm{OI}=10.4236 /$ jssm.2013.61010

[3] Damtew K, Pagidimarri V. The role of trust in building customer loyalty in insurance sector- A study. IOSR J Bus Manag. 2013;14(4):82-93.

[4] Vuuren V, Lombard R, Tonder V. Customer satisfaction, trust and commitment as predictors of customer loyalty within an optometric practice environment. South African Bus Rev. 2012;16(3):8196.

[5] Kotler P, Keller KL. Marketing Management 15th Edition. 15th ed. United States America: Pearson Education; 2016.

[6] Kotler P, Amstrong G. Principles of Marketing. 15 edition. United States: Pearson; 2014.

[7] Sandhu H, Bala M. Customers' Perception towards Service Quality of Life Insurance Corporation of India: A Factor Analytic Approach. Int J Bus Soc [Internet]. 2011;2(18):219-32. Available from: http://ijbssnet.com/journals/Vol_2_No_18_October_2 011/27.pdf

[8] Tjiptono F. Service Quality, and Satisfaction. Yogyakarta: Andi; 2012.

[9] Anjor P, Ali, Kumar M, Verma VK. Service Quality Assessment: A Study of Consumer Satisfaction in Indian Insurance Sector. IOSR J Businesss Manag [Internet]. 2014;16(3):34-41. Available from: www.iosrjournals.org

[10] Brady MK, Cronin JJJ. Some new thoughts on conceptualizing perceived service quality: a hierarchical approach. J Mark [Internet]. 2001;65(3):34-49. Available from: http://journals.ama.org/doi/abs/10.1509/jmkg.65.3.34. 18334

[11] Sukmawati I, Massie JD. Pengaruh Kualitas Pelayanan dimediasi Kepuasan Pelanggan dan Kepercayaan Pelanggan Terhadap Loyalitas Pelanggan Pada PT Air Manado. J EMBA. 2015;3(3):729-42.

[12] Pramana i GY, Rastini NM. Pengaruh Kualitas Pelayanan Terhadap Kepercayaan Nasabah dan Loyalitas Nasabah Bank Mandiri Cabang Veteran Denpasar Bali. E-jurnal Manaj UNUD. 2016;5(1):706-33.

[13] Pontoh MB, Kawet L, Tumbuan WA. Kualitas Layanan, Citra Perusahaan Dan Kepercayaan Pengaruhnya Terhadap Kepuasan Nasabah Bank Bri Cabang Manado. J EMBA. 2014;2(3):285-7.

[14] Parthiban. A Study on Service Quality Perceptions and Customer Satisfaction in Private Sector Life Insurance Companies: A Study with Special Reference to Chennai City. Int J Recent Innov Trends Comput Commun. 2011;2(10):3130-3.

[15] Qureshi MNZ, Bhat JA. An Assessment of Service Quality , Customer Satisfaction and Customer Loyalty in Life Insurance Corporation of India with Special 
Reference to Srinagar District of Jammu and Kashmir. Pacific Bus Rev Int. 2015;7(8):60-70.

[16] Cherchiello P. “ Innovation and Society 2011. Statistical Methods for the Evaluation of Services ( IES 2011 )" Measuring Risk Profile With A Multidimensional “ Innovation and Society 2011. Statistical Methods. Int Conf "Innovation Soc 2011 Stat Methods Eval Serv (IES 2011). 2011;(Ies):14-29.

[17] Chibuike R. Corporate Reputation \& Firm Perfonnance: Empirical Literature Evidence. Intemational Joumal Bus Manag. 2011;6(4):197-207.

[18] Altunbas H, Diker E. Corporate reputation management and social media analysis on facebook account of the most valuable 5 Brands in Turkey. Int Reput Manag Conf Kadir has Univ. 2015;40-54.

[19] Nova F. Crisis Public Relation. Jakarta: Raja Grafindo Persada; 2011.

[20] Sontaite S, Bakanauskas A. Measurement Model Of Corporate Reputation at Higher Education Institution : Customer's Perpective. Manag Organ Syst Res. 2011;59:1392-1142.

[21] Davies G, Chun R, Silva R Da, Roper S. Corporate Reputation And Competitiveness. London: Routledge; 2003.

[22] Keh HT, Xie Y. Industrial Marketing Management Corporate reputation and customer behavioral intentions: The roles of trust, identi fi cation and commitment. Ind Mark Manag [Internet]. Elsevier Inc.; 2009;38(7):732-42. Available from: http://dx.doi.org/10.1016/j.indmarman.2008.02.005

[23] Haery FA, Ghorbani H, Zamani B. Investigating the Relationship between Corporate Reputation and Customer Behavioral Intentions through Roles of Customer Trust , Customer Commitment and Customer Recognition ( Case Study: Iran Insurance Company in Iran, Isfahan City ). Int J Acad Res Bus
Soc Sci. 2014;4(4):470-84.

[24] Gozukara I, Yildirim O. Affective Commitment and Corporate Reputation . The Effects of Attitude toward Advertising and Trust. Acad J Econ Stud. 2015;1(3):126-47.

[25] Mayer RC, Davis JH, Schoorman FD. An Integrative Model of Organizational Trust. Acad Manag Rev [Internet].1995;20(3):709-34. Available from: http://www.jstor.org/stable/258792 Inhttp://www.jstor. org/stable/pdfplus/258792.pdf?acceptTC $=$ true

[26] Koc F, Ozbek V, Alniacik E. Procedia Social and Behavioral Sciences The moderating role of service environment on the effects of firm reputation and perceived service quality on consumer trust: A study in the healthcare industry. Procedia -Social Behav Sci [Internet]. 2014;00(November 2015):111-20. Available from: www.elsevier.com/locate/procedia

[27] Benson RJ, Ribbers PM, Blistein RB. Trust and Partnership: Strategic IT Management For Turbulent Times. New Jersey: John Wiley \& Sons Inc.; 2014.

[28] Diza F, Moniharapon S, Ogi IW. Pengaruh kualitas pelayanan, kualitas produk dan kepercayaan terhadap kepuasan konsumen (studi pada pt. fifgroup cabang manado). J EMBA. 2016;4(1):109-19.

[29] Mansor AA, Hasanordin R, Hafiz M, Rashid A, Edura W, Rashid W. Hierarchical Service Quality Model towards Student Satisfaction. Int $\mathrm{J}$ Innov. 2012;3(6):803-7.

[30] El-rafae BAAGA. The Relationships between Service Quality, Satisfaction, and Behavioral Intentions of Malaysian Spa Center Customers. Int J Bus Soc Sci. 2012;3(1):198-206.

[31] Kanto DS, Run EC de, Isa AH bin M. Developing an alternative measurement of corporate reputation within the Malaysian context. Interdiscip J Contemp Res Bus. 2013;5(1):730-8. 